\title{
Assessment of radioactive pollution around a fertilizer factory complex in the North-Eastern part of Bangladesh
}

\author{
S. GHOSE ${ }^{1 *}$, M. AKHTER ${ }^{2}$, S.M. AZHARUL ISLAM ${ }^{2}$, M. SHAHABUDDIN ${ }^{2}$, \\ M. MAZIBUR RAHMAN ${ }^{3}$
}

(Manuscript received 19 July 2012, accepted 2nd May 2013)

ABSTRACT The activity concentrations of soil, water and fertilizer samples were determined by using high-resolution gamma spectrometry (HPGe detector: $40 \%$ relative efficiency) with a PC-based MCA system. The samples were collected from the area of a urea fertilizer factory, lagoon and Shitalakhya river in Narsingdi, Bangladesh. The activity concentrations of ${ }^{226} \mathrm{Ra}$ ranged from $3.16 \pm 0.32$ to $10.28 \pm 0.55 \mathrm{~Bq} . \mathrm{kg}^{-1}, 1.22 \pm$ 0.41 to $7.36 \pm 0.42 \mathrm{~Bq} . \mathrm{L}^{-1}$ and $3.55 \pm 0.33$ to $90.65 \pm 3.17 \mathrm{~Bq} \cdot \mathrm{kg}^{-1}$ for soil, water and fertilizer samples, respectively. The ${ }^{232}$ Th activity concentrations ranged from $4.89 \pm$ 0.45 to $15.82 \pm 0.45 \mathrm{~Bq} . \mathrm{kg}^{-1}, 1.21 \pm 0.06$ to $8.59 \pm 0.37 \mathrm{~Bq} . \mathrm{L}^{-1}$ and $4.76 \pm 0.25$ to $26.38 \pm 1.40 \mathrm{~Bq} \cdot \mathrm{kg}^{-1}$ for soil, water and fertilizer samples, respectively. The ${ }^{40} \mathrm{~K}$ activity concentrations ranged from $24.96 \pm 0.23$ to $60.49 \pm 0.56 \mathrm{~Bq}^{-\mathrm{kg}^{-1}, 7.48 \pm 0.53 \text { to }}$ $35.48 \pm 0.24 \mathrm{~Bq} . \mathrm{L}^{-1}$ and $3.55 \pm 0.05$ to $3051.71 \pm 19.53 \mathrm{~Bq} \cdot \mathrm{kg}^{-1}$ for these samples, respectively. The radium equivalent activity, the hazard indices, the gamma activity concentration index, the indoor absorbed dose rate and the corresponding annual effective dose were estimated for the potential radiological hazard of the collected samples. The calculated values of the representative level index values (I $\gamma \mathbf{r})$ for all samples of the study area are lower than unity except the MOP sample. The activity ratios were also measured. These values are compared with reported values for other countries of the world. The results of the comparison studies show that the radioactivity concentrations and other radioactive indices of the samples of the study area are below the internationally accepted maximum permissible values. Therefore, this region is safe from any radiation hazard and no significant radiological threat was observed to the population of the study area.

Keywords: fertilizer / gamma spectrometry / radium, thorium and potassium

\section{Introduction}

High industrialization normally occurs with intense urbanization and environmental problems of cities. Noise, air and water pollution, occupational exposure, etc., are the direct impacts of urbanization and industrialization. Many of these effects

\footnotetext{
1 Nuclear Safety \& Radiation Control Division, Bangladesh Atomic Energy Commission, 4 Kazi Nazrul Islam Avenue, Ramna, Dhaka, Bangladesh.

2 Department of Physics, Jahangirnagar University, Savar, Dhaka, Bangladesh.

3 International Affairs Division, Bangladesh Atomic Energy Commission, Dhaka, Bangladesh.

* e-mail: ghosesatyajit@yahoo.com.
} 
are not particularly harmful in isolated contacts, but continued exposure to lowlevel environmental pollution may be a much more serious problem for health and environmental safety (Mourad et al., 2009).

Consequently, increasing attention has been paid to the many non-nuclear industries, which have the capability for low-level but consistent exposure to ionizing radiation. Such industries are capable of generating critical group or collective exposure or both; doses can be delivered both to plant workers and to populations living in the neighborhoods of plants. Cement industries, phosphateore industries (producing fertilizers, detergents and acids), the urea fertilizer industry, coal power plants, oil and gas extraction facilities and, to some extent, the ceramic industry are examples of these types of industries (Khan et al., 1998; UNEP, 1998; Bolivar et al., 2000, 2002; Righi et al., 2000; Alcaraz Pelegrina and Martinez-Aguirre, 2001; Khater et al., 2001; Brigden et al., 2002; Saueia and Mazzilli, 2006).

As with all chemical process industries, the production of mineral fertilizers gives rise to emissions, which contribute to environmental problems, both globally and locally. Much research and expenditure has been devoted to minimizing these emissions (Santos et al., 2006). Like other industries, the fertilizer industry started with plants which would be totally unacceptable today, both in terms of their waste emissions and their internal working environment. Atmospheric pollutions emitted by the fertilizer industry can include gaseous ammonia $\left(\mathrm{NH}_{3}\right)$ and ammonium salt aerosols, nitric and nitrous oxides, fluorine (as $\mathrm{SiF}_{4}$ and $\mathrm{HF}$ ), oxides of sulfur $\left(\mathrm{SO}_{\mathrm{x}}\right)$, fertilizer dust, acid mists, and radiation from phosphogypsum (Butchaiah et al., 2009; Hopke, 2009). Carbon dioxide is also emitted in large quantities by the fertilizer industry. Wastewater from the industry can include compounds of nitrogen, phosphate, potassium, sodium, silica, sulfur and fluorine, as well as sludge and polluted water. Solid wastes or by-products, which may or may not be reprocessed, can include phosphogypsum, calcium carbonate, soluble salts, sand and the plastic bags used to transport the fertilizer (UNEP, 1998).

Non-nuclear industries such as the fertilizer industry use raw material containing significant levels of natural radionuclides; the processing of these materials can expose the environment, workers and people living near such sites to radiation levels well above the natural background. The presence of elevated levels of $\mathrm{Ra}$, Th and $\mathrm{K}$ in fertilizer and in environmental (soil and water) samples around a fertilizer factory complex has been established in several previous studies (OlszewskaWasiolek, 1995; Alam et al., 1997; Khan et al., 1998; Righi et al., 2000; Khater et al., 2001; Bolivar et al., 2002; Ogunleye et al., 2002; El-Bahi et al., 2004; Abbady et al., 2005; Ahmed and El-Arabi, 2005; Saueia et al., 2005; Conceicao and Bonotto, 2006; El-Arabi et al., 2007; El-Aydarous, 2007; Ferdoas et al., 2007; 
Mourad et al., 2009). The general goal of many studies was to assess the environmental radioactive pollution and radiological impacts caused by a production plant of phosphate fertilizers (Alam et al., 1997; Ogunleye et al., 2002; Abbady et al., 2005; Ahmed and El-Arabi, 2005; Righi et al., 2005; Saueia and Mazzilli, 2006). Also, the assessment of fluoride and heavy metal pollution caused by such a plant was the objective of many investigations (El-Bahi et al., 2004; Wang et al., 2005; Loganathan et al., 2007). In particular, elevated concentrations of several natural radionuclides were found in water and soils collected from different rivers, beaches, oceans and other landscapes (UNSCEAR, 1982, 1988, 2000; Alam et al., 1999; Chowdhury et al., 1999; Ghose et al., 2000; Labidi et al., 2002; Somlai et al., 2002; Mireles et al., 2003; Cevik. et al., 2006; Chowdhury et al., 2006; Huy and Luyen, 2006; Khalifa, 2004; Mehra et al., 2007; Uchida et al., 2007; Radenkovic et al., 2009; Salbu and Skipperud, 2009). In the present study, to assess the impact of a urea fertilizer factory on the environment, the environmental pollution impact was analyzed by determining the concentrations of the radionuclides and other radioactive indices in soil, water and fertilizer samples which were collected from around the urea fertilizer plant, urea drain, lagoon, Shitalakhya river and the local market. Such information will lead to an accurate dosimetric evaluation of the risk of human exposure due to enhancements of TENORM (technologically-enhanced naturally occurring radioactive materials) levels.

\section{Materials and Methods}

\subsection{Study area}

The study area includes the inside and outside of a urea fertilizer factory in the district of Narsingdi which stands about $60 \mathrm{~km}$ away from the North-Eastern part of Dhaka on the bank of the river Sitalakhya. The basic raw material used in this factory for the production of urea is natural gas. The amount of gas used per hour is 50278 Normal $\mathrm{m}^{3} .43 .05 \%$ gas is used for urea processing and $56.95 \%$ used as fuel. In the first step, ammonia is produced from natural gas. Finally, urea is produced from the reaction of ammonia and carbon dioxide in certain thermodynamic conditions with the presence of a suitable catalyst. The installation capacity of this factory is 3,40,000 MT urea per year, 1137 MT urea per day and $660 \mathrm{MT}$ ammonia per day.

\subsection{Sampling}

In order to measure the natural radioactivity in the study area, soil, water and fertilizer samples were collected from different locations of the urea fertilizer factory. Soil samples were collected from twenty-five different locations, and water 
samples from fifteen different locations. The sampling locations for soil and water are inside and outside areas of the factory, the adjacent river Sitalakhya, the urea drain and the lagoon. The fertilizer samples were collected from local market. The location of sampling points are shown in Figure 1. All the soil samples were collected from an auger hole at a depth of about $15 \mathrm{~cm}$ from the ground. Samples were dried in an oven at a temperature of $110^{\circ} \mathrm{C}$ for $48 \mathrm{~h}$ to remove the moisture. Soil and fertilizer samples were crushed into fine powder by using a mortar and pestle. The fine quality of the samples was obtained using a 150-micron mesh size scientific sieve method. Each sample was packed and sealed in an airtight PVC container. The 15 2-1 water samples were collected from the 3 locations in 2-1 plastic containers. After collection, each 2-1 water sample was acidified with $20 \mathrm{ml}$ of $11 \mathrm{M}$ HCL to prevent adsorption of radionuclides on the container walls. The collected water samples were filtered through filter paper to remove very fine undissolved particles. For radionuclide measurements, each 2-1 water sample was evaporated to reduce the volume to $500 \mathrm{ml}$ and packed into $150-\mathrm{ml}$ cylindrical containers, sealed tightly, wrapped with thick vinyl tape around their screw necks and kept for about 4 weeks to achieve secular equilibrium between ${ }^{222} \mathrm{Rn}$ and ${ }^{226} \mathrm{Ra}$ (Tufail et al., 2000).

\subsection{Measurement of natural radioactivity}

The activity concentrations of studied samples were counted by using a $40 \% \mathrm{RE}$ HPGe detector based on the high-resolution gamma-spectrometry system. The detector is a co-axial p-type high-purity germanium detector (Model no. GC-4020 and serial no. 07037658). The detector has a resolution of $2.0 \mathrm{keV}$ and relative efficiency of $40 \%$ for $1332.5 \mathrm{keV}$ gamma energy of ${ }^{60} \mathrm{Co}$. The output of the detector is analyzed using a MCA system connected to a PC of 16384 channels. The spectral data is analyzed using the software "Genie 2000". The detector is shielded by a lead cylinder of thickness 3.7", height 15.98" and 15.59" internal diameter. The upper side of the lead cylinder is covered by a lead plate of diameter $19^{\prime \prime}$ and thickness 3.54" to reduce the background level of the system. The efficiency calibration for the system is carried out using a secondary standard source in geometry available for the sample counting. Gamma transitions of $1,460 \mathrm{keV}$ for ${ }^{40} \mathrm{~K}, 295$ and $352 \mathrm{keV}$ of ${ }^{214} \mathrm{~Pb}, 609$ and $1120 \mathrm{keV}$ of ${ }^{214} \mathrm{Bi}$ for ${ }^{226} \mathrm{Ra}$, and 911 and $969 \mathrm{keV}$ of ${ }^{228} \mathrm{Ac}$ for ${ }^{238} \mathrm{Th}$ were used for the laboratory measurement of the activity concentration of potassium, radium and thorium. The spectrum of every soil sample was collected for $50 \mathrm{ks}$.

The net count rate under the most prominent photo peaks of radium and thorium daughter peaks are calculated by subtracting the respective count rate from the background spectrum obtained for the same counting time. The 


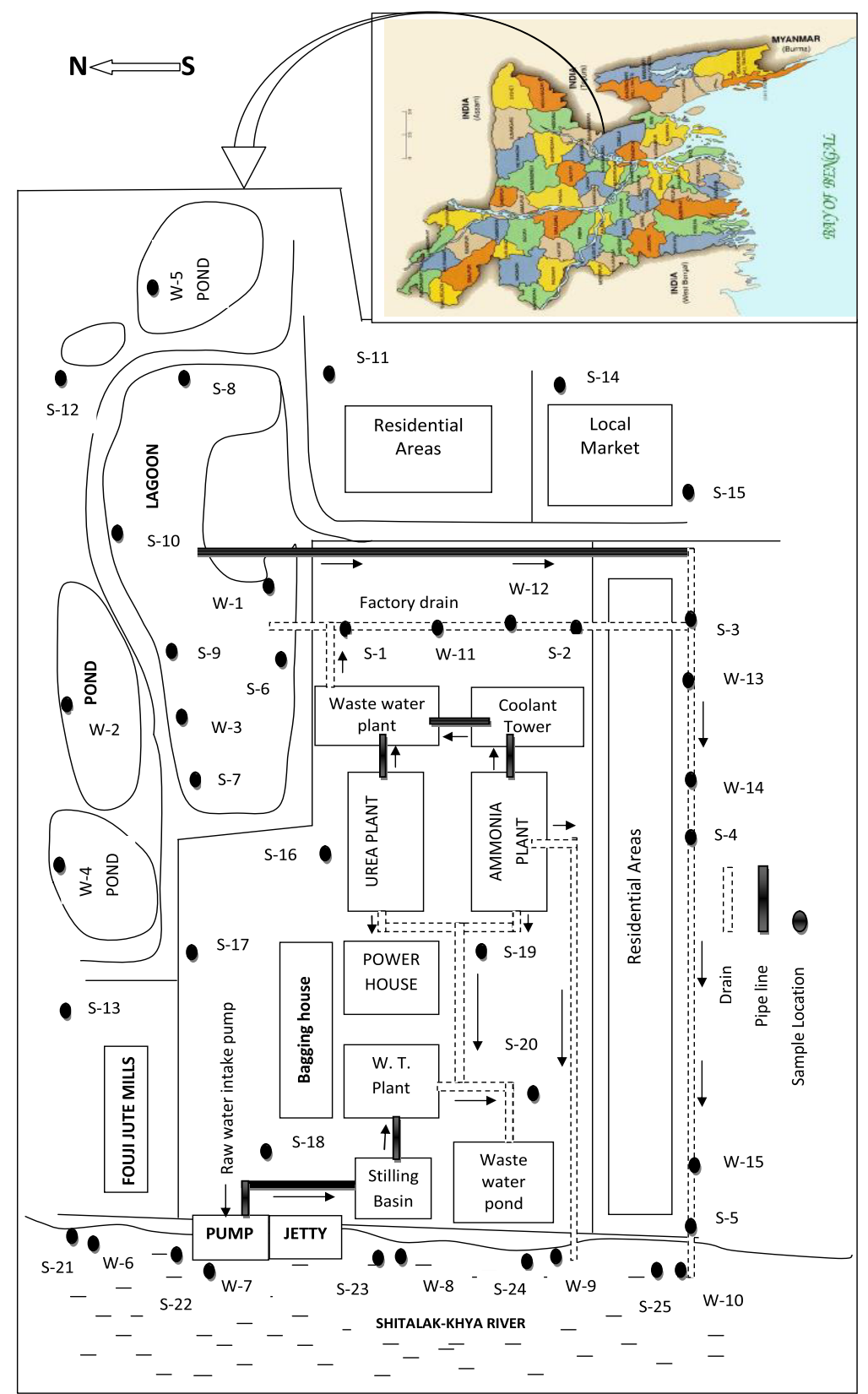

Figure 1 - The sampling locations of the Urea fertilizer factory. 
concentrations of radionuclides are calculated using the following equation (1) (Righi et al., 2005):

$$
\mathrm{A}=\frac{\mathrm{cps}}{\mathrm{E} \mathrm{I} \mathrm{W(in} \mathrm{kg)}} \pm \sigma
$$

where $\mathrm{A}=$ activity of the sample in Bq. $\mathrm{kg}^{-1}$, $\mathrm{cps}=$ net counts per second ( $\mathrm{cps}$ for sample - cps for background), $\mathrm{E}=$ the counting efficiency of the gamma energy = $\frac{\mathrm{cps}}{\mathrm{dps} \mathrm{I} \mathrm{W}}, \mathrm{I}=$ absolute intensity of the gamma ray and $\mathrm{W}=$ sample net weight.

The errors in the measurements are expressed in terms of the standard deviation $(\sigma)$, which is expressed as:

$$
\sigma=\left[\frac{N_{s}}{T_{s}^{2}}+\frac{N_{b}}{T_{b}^{2}}\right]^{1 / 2}
$$

where $N_{s}$ is the sample counts measured in time $T_{s}$ and $N_{b}$ is the number of background counts in time $T_{b}$.

\subsection{Radium equivalent activity}

The distribution of ${ }^{226} \mathrm{Ra},{ }^{232} \mathrm{Th}$ and ${ }^{40} \mathrm{~K}$ in soil is not uniform. Uniformity with respect to exposure to radiation has been defined in terms of radium equivalent activity $\left(\mathrm{Ra}_{\mathrm{eq}}\right)$ in Bq. $\mathrm{kg}^{-1}$ to compare the specific activity of materials containing different amounts of ${ }^{226} \mathrm{Ra},{ }^{232} \mathrm{Th}$ and ${ }^{40} \mathrm{~K}$. It is calculated through the following relation (Mehra et al., 2007):

$$
\mathrm{Ra}_{\mathrm{eq}}=\mathrm{C}_{\mathrm{Ra}}+1.43 \mathrm{C}_{\mathrm{Th}}+0.077 \mathrm{C}_{\mathrm{k}}
$$

where $\mathrm{C}_{\mathrm{Ra}}, \mathrm{C}_{\mathrm{Th}}$ and $\mathrm{C}_{\mathrm{k}}$ are the activity concentrations of ${ }^{226} \mathrm{Ra},{ }^{232} \mathrm{Th}$ and ${ }^{40} \mathrm{~K}$, respectively, in $\mathrm{Bq} \cdot \mathrm{kg}^{-1}$.

\subsection{Representative level index values}

To estimate the level of $\gamma$-radiation hazard associated with the natural radionuclides in the materials, the representative level index was calculated on the basis of $\mathrm{Ra}$, Th and $\mathrm{K}$ concentration levels in the studied samples using the following equation derived by NEA-OECD (1979):

$$
\mathrm{I} \gamma \mathrm{r}=\left(\frac{1}{150}\right) C_{R a}+\left(\frac{1}{100}\right) C_{T h}+\left(\frac{1}{1500}\right) C_{K}
$$


where $\mathrm{C}_{\mathrm{Ra}}, \mathrm{C}_{\mathrm{Th}}$ and $\mathrm{C}_{\mathrm{k}}$ are the specific activities of ${ }^{226} \mathrm{Ra},{ }^{232} \mathrm{Th}$ and ${ }^{40} \mathrm{~K}$ in $\mathrm{Bq} \cdot \mathrm{kg}^{-1}$. This index value must be less than unity in order to keep the radiation hazard insignificant, i.e., the radiation exposure due to radioactivity from soil, water and fertilizer samples is limited to unity (Mirjana et al., 2009).

\subsection{Dose rate calculation}

The total absorbed dose rate (D) in the air (outdoors) due to the uniform distribution of all the ${ }^{226} \mathrm{Ra}$ and ${ }^{232} \mathrm{Th}$ and ${ }^{40} \mathrm{~K}$ in the samples $1 \mathrm{~m}$ above the ground surface was estimated by the formula (UNSCEAR, 1988):

$$
\mathrm{D}=0.427 \mathrm{C}_{\mathrm{Ra}}+0.662 \mathrm{C}_{\mathrm{Th}}+0.0432 \mathrm{C}_{\mathrm{k}}\left(\mathrm{nGy} \cdot \mathrm{h}^{-1}\right)
$$

where $\mathrm{C}_{\mathrm{Ra}}, \mathrm{C}_{\mathrm{Th}}$ and $\mathrm{C}_{\mathrm{k}}$ are, respectively, the average activity concentrations of $\mathrm{Ra}$, $\mathrm{Th}$ and $\mathrm{K}$ contents in samples in Bq. $\mathrm{kg}^{-1}$.

\section{Results and discussion}

\subsection{Soil and water samples}

The activity concentrations determined for the radionuclides in the analyzed soil samples are listed in Table I. The presented results of the contents of radionuclides in soil samples, taken from the urea drain and inside the factory, show low activity concentrations of ${ }^{226} \mathrm{Ra},{ }^{232} \mathrm{Th}$ and ${ }^{40} \mathrm{~K}$. The minimum activity concentration, $3.16 \pm 0.32 \mathrm{~Bq} \cdot \mathrm{kg}^{-1}$ of ${ }^{226} \mathrm{Ra}$, was determined in the soil sample from inside the factory, while the maximum value of $10.28 \pm 0.55 \mathrm{~Bq} \cdot \mathrm{kg}^{-1}$ was found in the soil from Sitalakhya river. The activity concentrations of ${ }^{232} \mathrm{Th}$ were in the range $4.89 \pm 0.45-15.82 \pm 0.45 \mathrm{~Bq} \cdot \mathrm{kg}^{-1}$, with a minimum value for inside the factory and a maximum for the Sitalakhya river. The content of ${ }^{40} \mathrm{~K}$ had the lowest value of $24.96 \pm 0.23 \mathrm{~Bq} \cdot \mathrm{kg}^{-1}$ for the soil sample from inside the factory and relatively higher values up to $60.49 \pm 0.56 \mathrm{~Bq} \cdot \mathrm{kg}^{-1}$ for the soils from the urea drain, and inside and outside the factory.

These results are comparatively lower in accordance with previous studies in Egypt (21.5 (15.4-33.8), 14.2 (10.4-19.3), 219 (128-281) Bq. kg ${ }^{-1}$ ) (Mourad et al., 2009), the Bangladeshi river Karnaphuli $35.9 \pm 18.9(18.4 \pm 2.6-85.2 \pm 8.4)$, $\left.65.5 \pm 12.2(50.8 \pm 4.2-88.4 \pm 7.7), 272 \pm 35(217 \pm 15.5-320 \pm 21) \mathrm{Bq} \cdot \mathrm{kg}^{-1}\right)$ and Sangu $(27.8 \pm 2.9(31.9 \pm 3.7-24 \pm 3.0), 57.5 \pm 3.0(52.4 \pm 5.5-61.7 \pm 6.7), 255 \pm$ $\left.18(212 \pm 15-292 \pm 18) \mathrm{Bq} \cdot \mathrm{kg}^{-1}\right)$ and the coastal soil of Chittagong $(34.6 \pm 20.8$ $(14.0 \pm 0.5-89.2 \pm 6.4), 60 \pm 29.2(28.3 \pm 2.4-129 \pm 10.4), 438 \pm 142(200 \pm$ $\left.22-772 \pm 33) \mathrm{Bq}_{\mathrm{kg}}{ }^{-1}\right)($ Chowdhury et al., 1999), a southern district of Bangladesh $(42,81,833$ Bq.kg-1) (Chowdhury et al., 2006), the Um Sleimat area of Egypt 
S. GHOSE et al.

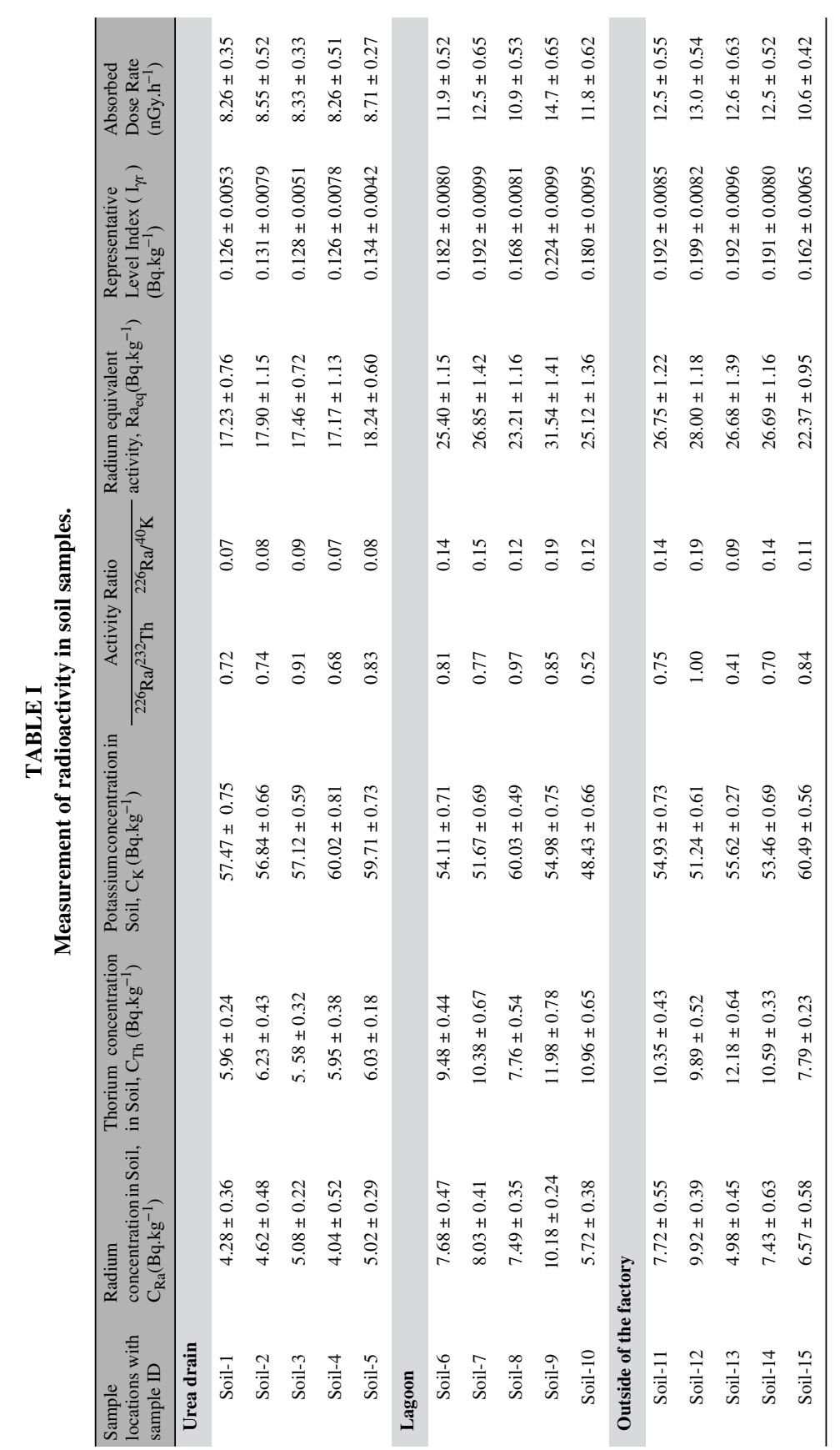


ASSESSMENT OF RADIOACTIVE POLLUTION AROUND A FERTILIZER FACTORY COMPLEX

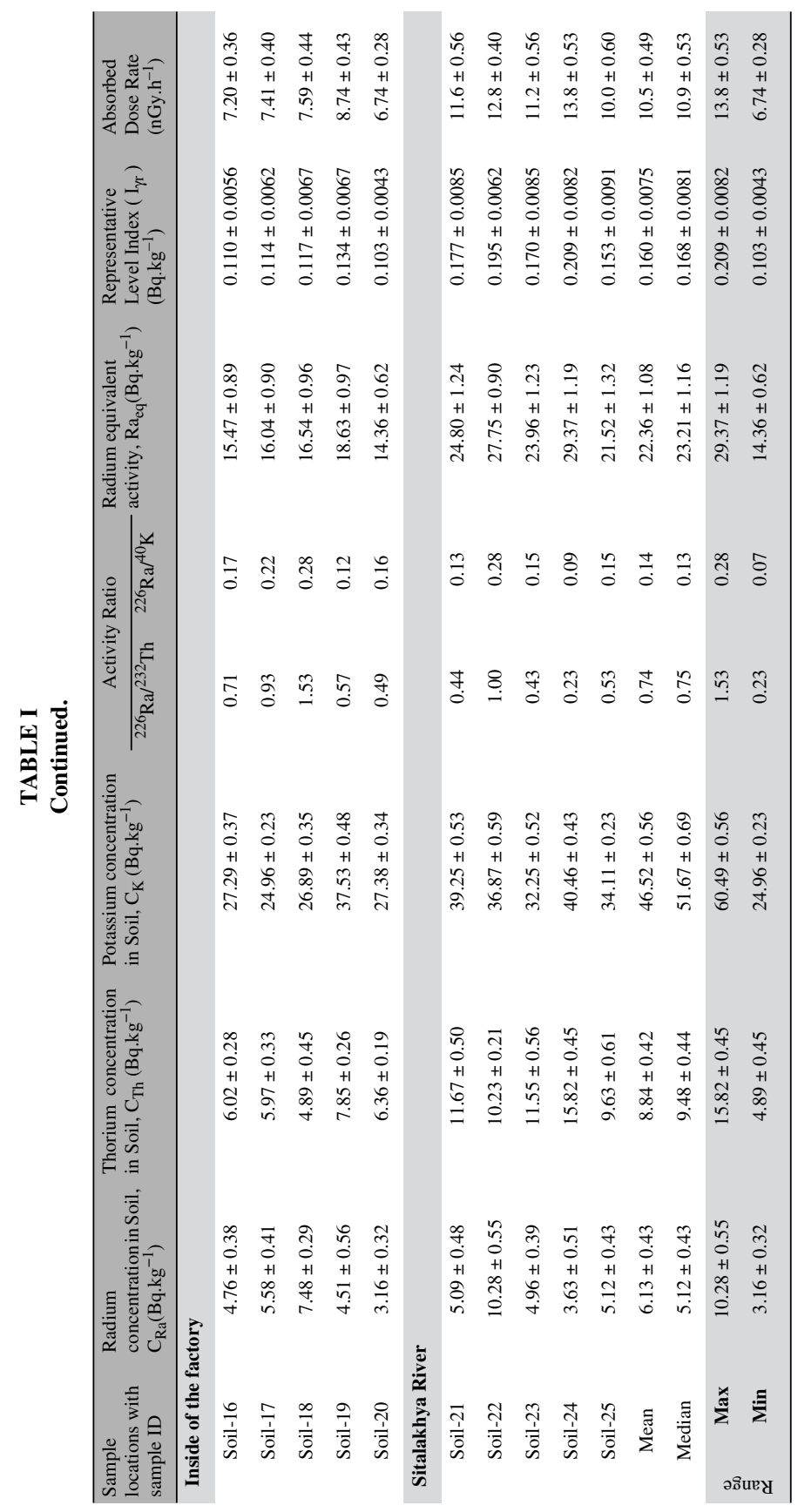

RADIOPROTECTION - VOL. 48 - N 4 (2013) 
$(77.9 \pm 8.7(45.5 \pm 7-130 \pm 11), 52.8 \pm 7.2(36.7 \pm 6-77.5 \pm 9), 1424.9 \pm 38$ $\left.(1299.7 \pm 36-1521.6 \pm 39) \mathrm{Bq} \cdot \mathrm{kg}^{-1}\right)$ (El-Arabi et al., 2007)), Taif in Saudi Arabia $(23.8 \pm 2.4(13 \pm 1.2-33 \pm 3.4), 18.6 \pm 1.7(11 \pm 1-27 \pm 4.2), 162.8 \pm 7.6(129 \pm$ $\left.5.7-230 \pm 11) \mathrm{Bq} \cdot \mathrm{kg}^{-1}\right)$ (El-Aydarous, 2007), the South-East of Vietnam (19.6, 31, 34.6 Bq. $\mathrm{kg}^{-1}$ ) (Huy and Luyen, 2006), and Mexico (Zacatecas and Guandalupe) $\left(23,19,530 \mathrm{~Bq} \cdot \mathrm{kg}^{-1}\right)$ (Mireles et al., 2003), as well as world quoted values for soils (25 (7-50), 25 (10-50) and 370 (100-700) Bq.kg-1) (Mirjana et al., 2009) for ${ }^{226} \mathrm{Ra},{ }^{232} \mathrm{Th}$ and ${ }^{40} \mathrm{~K}$, respectively. Therefore, it can be concluded that due to the activity concentrations of ${ }^{226} \mathrm{Ra},{ }^{232} \mathrm{Th}$ and ${ }^{40} \mathrm{~K}$ in the soil, none of the studied samples is considered a radiological hazard and this area is safe.

A comparison of radionuclide concentrations in the water of the three regions in the study area is shown in Table II. The water sample collected from the urea drain shows a higher content of ${ }^{226} \mathrm{Ra}\left(7.36 \pm 0.42 \mathrm{~Bq} . \mathrm{L}^{-1}\right)$ than the other two regions. The maximum amounts of ${ }^{232} \mathrm{Th}\left(8.59 \pm 0.37 \mathrm{~Bq} . \mathrm{L}^{-1}\right)$ and ${ }^{40} \mathrm{~K}(35.48 \pm$ $\left.0.24 \mathrm{~Bq} . \mathrm{L}^{-1}\right)$ were found in the water samples collected from the lagoon beside the urea fertilizer factory. The lowest concentrations of ${ }^{226} \mathrm{Ra}\left(1.22 \pm 0.41 \mathrm{~Bq} \cdot \mathrm{L}^{-1}\right)$, ${ }^{232} \mathrm{Th}\left(1.21 \pm 0.06 \mathrm{~Bq} \cdot \mathrm{L}^{-1}\right)$ and ${ }^{40} \mathrm{~K}\left(7.48 \pm 0.53 \mathrm{~Bq} \cdot \mathrm{L}^{-1}\right)$ were found in the water samples collected from Sitalakhya river.

A comparative study of the activity concentrations of ${ }^{226} \mathrm{Ra},{ }^{232} \mathrm{Th}$ and ${ }^{40} \mathrm{~K}$ in water samples of the study area with the previous measurements from different countries of the world shows the average activities of ${ }^{226} \mathrm{Ra}$ are higher than those observed in Egypt (0.58 Bq.L ${ }^{-1}$ ) (Mourad et al., 2009), the Chittagong Region of Bangladesh (drinking water: $0.043 \pm 0.017 \mathrm{~Bq} . \mathrm{L}^{-1}$ ) (Alam et al., 1999), the Eastern Black Sea region of Turkey (tap water: 0.019 Bq.L $\mathrm{L}^{-1}$ ) (Cevik et al., 2006), Qena, Egypt (drinking water: $0.048 \pm 0.0259$ Bq.L ${ }^{-1}$, groundwater: $0.07918 \pm$ 0.02886 Bq.L $\mathrm{L}^{-1}$ ), Safaga-Quseir, Egypt (drinking water: $0.05624 \pm 0.02849 \mathrm{~Bq} . \mathrm{L}^{-1}$, groundwater: $0.11285 \pm 0.0333 \mathrm{~Bq} \cdot \mathrm{L}^{-1}$ ) (Khalifa, 2004), Tunisia (springs: $0.03404-3.8961$ Bq..$^{-1}$ ) (Labidi et al., 2002) and Hungary (bottled mineral water: 0.0999 to 2.997 Bq.L ${ }^{-1}$ ) (Somlai et al., 2002), while they are lower than those found in the Portuguese rivers Tejo and Duro (16.2 \pm 6.7 and $19.8 \pm$ 8.7 Bq. $\mathrm{L}^{-1}$ ), and the Bay of Bengal (surface seawater: $5.4 \pm 2.4$ to $29.0 \pm 8.3 \mathrm{~Bq} . \mathrm{L}^{-1}$ ) (Ghose et al., 2000). A very high concentration of ${ }^{226} \mathrm{Ra}$ was reported in the Ikaria Sea $\left(1200 \pm 1000\right.$ Bq.L $\left.\mathrm{L}^{-1}\right)$, French rivers (1 to 730 Bq.L $\left.{ }^{-1}\right)$ and Czechoslovakia (10 to $3800 \mathrm{~Bq} . \mathrm{L}^{-1}$ ) (Ghose et al., 2000). On the other hand, the average activity of this radionuclide in the area also closely agrees with the Chinese river, Yangtze (2.8-8.9 Bq. $\left.\mathrm{L}^{-1}\right)$, a Greek region $\left(1.5 \pm 0.3-1.7 \pm 0.4\right.$ Bq. $\left.\mathrm{L}^{-1}\right)$ and the UK $(1.3-$ 3.1 Bq.L ${ }^{-1}$ ) (Ghose et al., 2000). The measured activity concentrations of ${ }^{232} \mathrm{Th}$ $\left(3.82 \pm 0.24 \mathrm{~Bq} . \mathrm{L}^{-1}\right)$ in the same water samples are higher than the previous results from Egypt (0.05 Bq.L ${ }^{-1}$ ) (Mourad et al., 2009), the Chittagong Region of Bangladesh (drinking water: $0.19 \pm 0.05$ Bq.L ${ }^{-1}$ ) (Alam et al., 1999), Qena, Egypt 


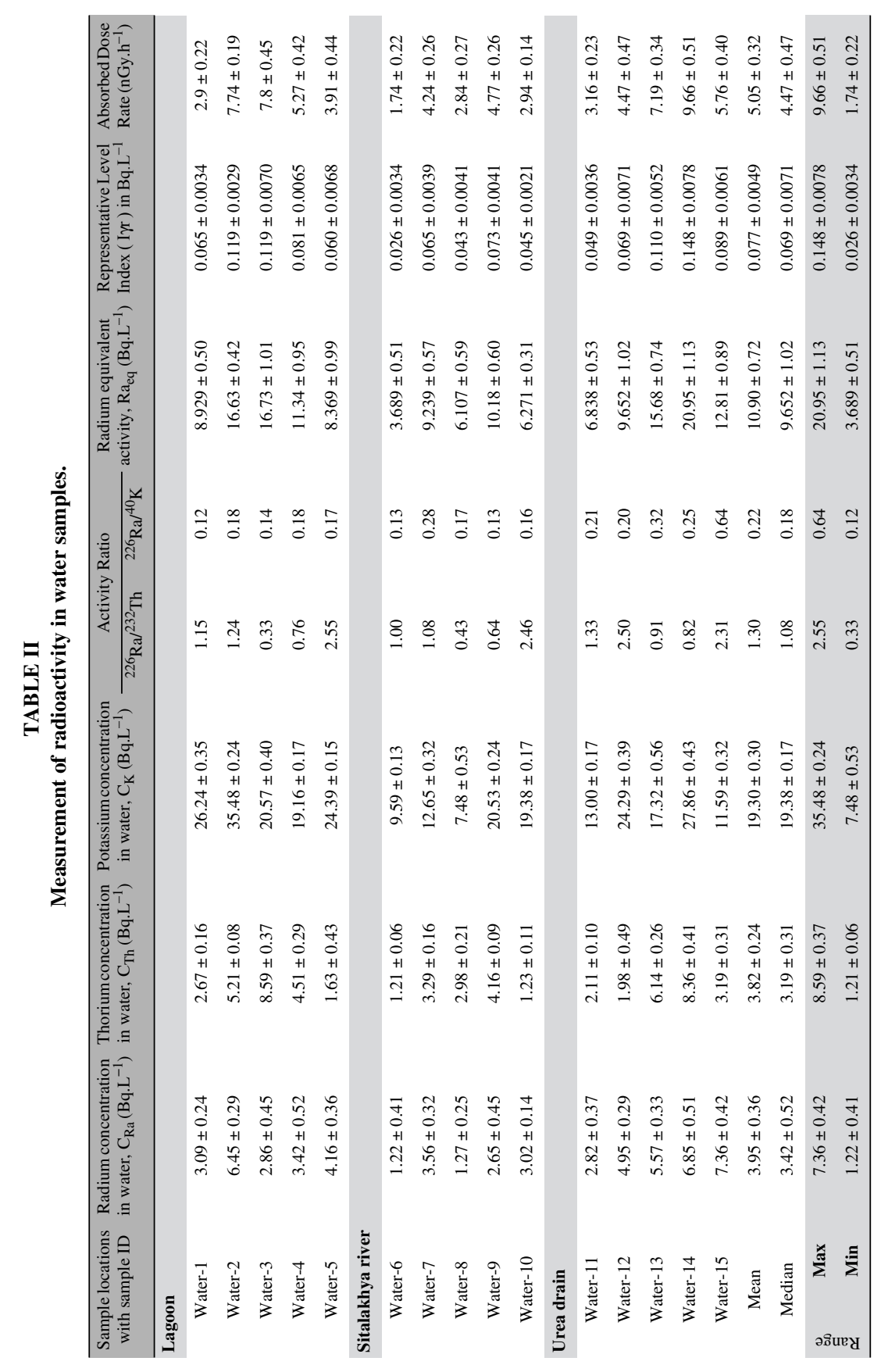


(drinking water: $0.02738 \pm 0.01628$ Bq.L ${ }^{-1}$, groundwater: $0.0407 \pm 0.02294$ Bq. $\mathrm{L}^{-1}$ ) and Safaga-Quseir, Egypt (drinking water: $0.02923 \pm 0.01665$ Bq.L ${ }^{-1}$, groundwater: $\left.0.05143 \pm 0.0222 \mathrm{~Bq} . \mathrm{L}^{-1}\right)\left(\right.$ Khalifa, 2004). The concentration observed for ${ }^{40} \mathrm{~K}$ is higher than that of the reported value from Egypt (0.05 Bq.L ${ }^{-1}$ ) (Mourad et al., 2009), the Eastern Black Sea region of Turkey (tap water: 0.019 Bq.L $\left.{ }^{-1}\right)($ Cevik et al., 2006) and the Chittagong Region of Bangladesh (drinking water: $4.16 \pm$ 1.58 Bq. $\mathrm{L}^{-1}$ ) (Alam et al., 1999).

The gamma-ray radiation hazards due to the specified radionuclides were also assessed by the indices, i.e., the radium equivalent activity $\left(\mathrm{Ra}_{\mathrm{eq}}\right)$, the activity ratio, the representative level index (I $\gamma \mathrm{r})$ and the absorbed dose rate. The results obtained for the soils and waters studied in this work are presented in Tables I and II. The presented results show that the $\mathrm{Ra}_{\mathrm{eq}}$ index for the soil samples had values in the range $14.36 \pm 0.62 \mathrm{~Bq} \cdot \mathrm{kg}^{-1}$ (inside the fertilizer factory) to $29.37 \pm$ $1.19 \mathrm{~Bq} \cdot \mathrm{kg}^{-1}$ (Sitalakhya river) compared with the population-weighted average value of global primordial radiation of $59 \mathrm{~Bq} \cdot \mathrm{kg}^{-1}$ (Mirjana et al., 2009). For water samples the $\mathrm{Ra}_{\mathrm{eq}}$ ranges from $3.689 \pm 0.51$ to $20.95 \pm 1.13 \mathrm{~Bq} \cdot \mathrm{L}^{-1}$. The index value I $\gamma \mathrm{r}$ must be less than unity in order to keep the radiation hazard insignificant (Ferdoas et al., 2007). The calculated values of $\mathrm{I} \gamma \mathrm{r}$ were within the limit value of $0.209 \pm 0.0082-0.103 \pm 0.0043 \mathrm{~Bq} \cdot \mathrm{kg}^{-1}$ for soil and $0.026 \pm 0.0034$ to $0.148 \pm$ $0.0078 \mathrm{~Bq} . \mathrm{L}^{-1}$ for water. The values of absorbed dose rates in samples range from $6.74 \pm 0.28-13.8 \pm 0.53 \mathrm{nGy} \cdot \mathrm{h}^{-1}$ with a mean of $10.5 \pm 0.49 \mathrm{nGy} \cdot \mathrm{h}^{-1}$ for soil and $9.66 \pm 0.51-1.74 \pm 0.22 \mathrm{nGy} \cdot \mathrm{h}^{-1}$ with a mean of $5.05 \pm 0.32 \mathrm{nGy} \cdot \mathrm{h}^{-1}$ for water, i.e., the measured values are less than the world average of $55 \mathrm{nGy} \cdot \mathrm{h}^{-1}$ (UNSCEAR, 1998). The ${ }^{226} \mathrm{Ra} /{ }^{232} \mathrm{Th}$ activity ratio varies in the ranges $0.33-2.55$ for water samples, and $0.23-1.53$ for soil. The ${ }^{226} \mathrm{Ra} /{ }^{40} \mathrm{~K}$ activity ratios are in the ranges $0.07-0.28$ for soils, and $0.12-0.64$ for water. Therefore, it can be concluded that the surface radiation dose for the study area is within the global range.

\subsection{Fertilizer samples}

The measured radioactivity concentrations of ${ }^{226} \mathrm{Ra},{ }^{232} \mathrm{Th}$ and ${ }^{40} \mathrm{~K}$ and the values of radiation hazard parameters in different fertilizers are shown in Table III. The radioactivity of ${ }^{226} \mathrm{Ra}$ in different fertilizers ranged from $3.55 \pm 0.33$ to $90.65 \pm$ 3.17 Bq. $\mathrm{kg}^{-1}$. Sulfur (S), MOP (muriate of potash) (KCl), TSP (triple superphosphate) $\left[\mathrm{Ca}\left(\mathrm{H}_{2} \mathrm{PO}_{4}\right)_{2} \cdot \mathrm{H}_{2} \mathrm{O}\right]$ and DAP (diammonium phosphate) $\left[\left(\mathrm{NH}_{4}\right)_{2} \mathrm{PO}_{4}\right]$ contained high contents of ${ }^{226} \mathrm{Ra}$. Urea is produced from natural gas, nitrogen and water; the presence of small amounts of ${ }^{226} \mathrm{Ra},{ }^{232} \mathrm{Th}$ and ${ }^{40} \mathrm{~K}$ may be due to impurities present in the raw materials. The radioactivity of ${ }^{226} \mathrm{Ra}$ in TSP was $90.65 \pm$ 3.17 Bq. kg ${ }^{-1}$, in DAP $46.46 \pm 2.32 \mathrm{~Bq} \cdot \mathrm{kg}^{-1}$, in MOP $4.90 \pm 0.39 \mathrm{~Bq} \cdot \mathrm{kg}^{-1}$, and in sulfur $55.20 \pm 2.15 \mathrm{~Bq} \cdot \mathrm{kg}^{-1}$. The ${ }^{226} \mathrm{Ra},{ }^{232} \mathrm{Th}$ and ${ }^{40} \mathrm{~K}$ concentrations determined 
ASSESSMENT OF RADIOACTIVE POLLUTION AROUND A FERTILIZER FACTORY COMPLEX

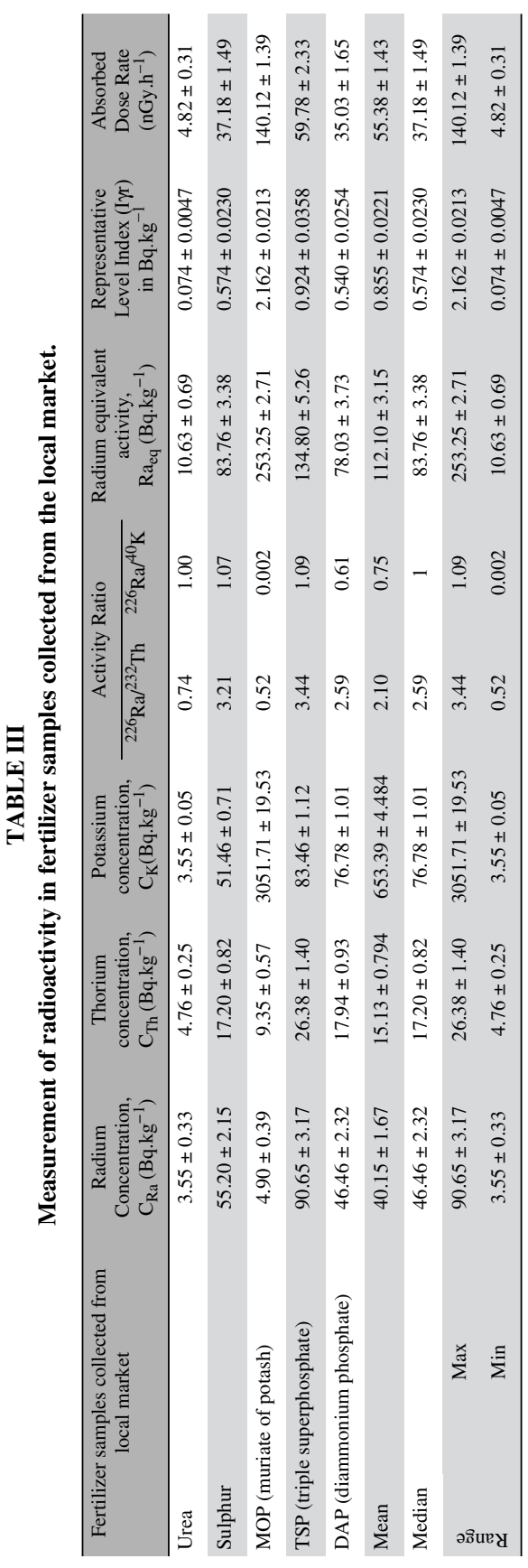

RADIOPROTECTION - VOL. 48 - N 4 (2013) 
in this work for urea fertilizer $\left(3.55 \pm 0.33,4.76 \pm 0.25\right.$ and $3.55 \pm 0.05 \mathrm{~Bq} \cdot \mathrm{kg}^{-1}$, respectively) were found to be lower than those reported for TSP $(90.65 \pm 3.17$, $26.38 \pm 1.40$ and $\left.83.46 \pm 1.12 \mathrm{~Bq} \cdot \mathrm{kg}^{-1}\right)$, DAP $(46.46 \pm 2.32,17.94 \pm 0.93$ and $\left.76.78 \pm 1.01 \mathrm{~Bq} \cdot \mathrm{kg}^{-1}\right), \mathrm{MOP}\left(4.90 \pm 0.39,9.35 \pm 0.57\right.$ and $\left.3051.71 \pm 19.53 \mathrm{~Bq} \cdot \mathrm{kg}^{-1}\right)$ and sulfur $\left(55.20 \pm 2.15,17.20 \pm 0.82,51.46 \pm 0.71 \mathrm{~Bq}_{\mathrm{kg}}{ }^{-1}\right)$ for the same radionuclides, which agreed with Alam et al. (1997) $(5.4 \pm 1.5,3.4 \pm 1.7$ and $7.9 \pm$ $2.4 \mathrm{~Bq} \cdot \mathrm{kg}^{-1}$ in urea). Hence, the probability of increasing the radioactivity level in soil is meager when using the urea fertilizer in cultivation rather than TSP, DAP, MOP, sulfur, phosphogypsum and single superphosphate.

A review of the worldwide data on natural radioactivity in fertilizers was presented in UNSCEAR reports $(1988,2000)$. The concentrations of ${ }^{226} \mathrm{Ra},{ }^{232} \mathrm{Th}$ and ${ }^{40} \mathrm{~K}$ of the present study $\left(90.65 \pm 3.17,26.38 \pm 1.40\right.$ and $\left.83.46 \pm 1.12 \mathrm{~Bq} \cdot \mathrm{kg}^{-1}\right)$ are comparable with the reported concentrations of the same radionuclides in TSP fertilizer in Egypt (Mourad et al., 2009) $\left(516 \pm 23,6.5 \pm 3.6\right.$ and $107 \pm 20 \mathrm{~Bq} \cdot \mathrm{kg}^{-1}$ ), Pakistan (Khan et al., 1998) (558.6, 84.8 and 143 Bq.kg-1), Brazil (Saueia et al., 2005) $\left(122 \pm 6,538 \pm 36\right.$ and $\left.147 \pm 17 \mathrm{~Bq} \cdot \mathrm{kg}^{-1}\right)$ and Bangladesh (Alam et al., 1997) $\left(323.8 \pm 24.4,22.0 \pm 2.8\right.$ and $\left.241.0 \pm 4.2 \mathrm{~Bq} \cdot \mathrm{kg}^{-1}\right)$.

The average activity of ${ }^{232} \mathrm{Th}$ in the different fertilizers ranged from $4.76 \pm$ 0.25 to $26.38 \pm 1.40 \mathrm{~Bq} \cdot \mathrm{kg}^{-1}$; the highest activity was observed in TSP fertilizer and the lowest was observed in urea fertilizer. The ${ }^{232} \mathrm{Th}$ activity of the present study in phosphate fertilizers is very much lower than the value reported by Conceicao and Bonotto (2006) and Saueia et al. (2005) and exceeds the values reported in Egypt (Mourad et al., 2009), Israel (Sam and Holm, 1995), and Algeria, Jordan, Tunisia and Sudan (Olszewska-Wasiolek, 1995). The activity of ${ }^{40} \mathrm{~K}$ was found to be high in the fertilizer muriate of potash (MOP), which contained a ${ }^{40} \mathrm{~K}$ activity of $3051.71 \pm 19 \mathrm{~Bq} \cdot \mathrm{kg}^{-1}$. The activity of ${ }^{40} \mathrm{~K}$ in TSP fertilizer $(83.46 \pm$ 1.12Bq. $\mathrm{kg}^{-1}$ ) is lower than the values in Egypt (Mourad et al., 2009), Bangladesh (Alam et al., 1997) and Pakistan (Khan et al., 1998).

The isotope ratios of the fertilizer samples (mean value of Tab. III) and the soil samples (mean value of Tab. I) for the measured radionuclides ${ }^{226} \mathrm{Ra},{ }^{232} \mathrm{Th}$ and ${ }^{40} \mathrm{~K}$ are $0.15,0.58$ and 0.08 . The data confirms that the fertilizer plant has very low radiological consequences on the surroundings.

The absorbed dose rates were in the range $4.82-140.12 \mathrm{nGy} \cdot \mathrm{h}^{-1}$ with an average value of $55.38 \mathrm{nGy} \cdot \mathrm{h}^{-1}$ for fertilizer samples. The value given for the absorbed dose rate is $44 \mathrm{nGy} \cdot \mathrm{h}^{-1}$, while a higher value of $55 \mathrm{nGy} \cdot \mathrm{h}^{-1}$ (UNSCEAR, 1982), (24-85 $\left.\mathrm{nGy} \cdot \mathrm{h}^{-1}\right)$ is the cited value for terrestrial radiation in 23 countries worldwide (UNSCEAR, 1988). The UNSCEAR report gave a wider range (18-93 $\mathrm{nGy} . \mathrm{h}^{-1}$ ) with an average value of $59 \mathrm{nGy} \cdot \mathrm{h}^{-1}$ (UNSCEAR, 2000). The 
results showed that the absorbed dose rates for the fertilizer samples are comparable with the world limits. The $\mathrm{Ra}_{\mathrm{eq}}$ concentration in fertilizer samples determined in this study showed a wide range (10.63-253.25 Bq. $\left.\mathrm{kg}^{-1}\right)$ and other reported values by Ogunleye et al. (2002) (584 and $1095.9 \mathrm{~Bq} \cdot \mathrm{kg}^{-1}$ ), Ahmed and El-Arabi (2005) (461.7 Bq. $\mathrm{kg}^{-1}$ ) exceed this range. The $\mathrm{Ra}_{\mathrm{eq}}$ concentration determined in this work for fertilizer is lower than that reported by El-Bahi et al. (2004) (992.36 and 1005.84 Bq. $\mathrm{kg}^{-1}$ ) and Saueia et al. (2005) (902.66 Bq. $\left.\mathrm{kg}^{-1}\right)$. The representative level index ranged from 0.074 to $2.162 \mathrm{~Bq} \cdot \mathrm{kg}^{-1}$ with an average value of $0.855 \mathrm{~Bq} \cdot \mathrm{kg}^{-1}$ for fertilizer samples, which is lower than that of Khan et al. (1998) (12.12 Bq. $\left.\mathrm{kg}^{-1}\right)$ and Saueia et al. (2005) (7.92 Bq. $\left.\mathrm{kg}^{-1}\right)$. The activity ratio of ${ }^{226} \mathrm{Ra} / 232 \mathrm{Th}$ ranged from 0.52 to 3.44 with a mean of 2.10 , and the ratio for ${ }^{226} \mathrm{Ra} /{ }^{40} \mathrm{~K}$ ranged from 0.002 to 1.09 with a mean of 0.75 in different fertilizers. These values are within the range of Mourad et al. (2009) and Khan et al. (1998) and exceed the values reported in Saueia et al. (2005).

\section{Conclusion}

The results showed that the ${ }^{226} \mathrm{Ra},{ }^{232} \mathrm{Th}$ and ${ }^{40} \mathrm{~K}$ concentrations in all types of studied environmental and fertilizer samples are lower compared with the maximum permissible limit set by various international organizations and the results of other studies, with a few exceptions. We therefore conclude that the study area does not pose any radiological hazard. The data presented in this study will also serve as a baseline survey of primordial radionuclide concentrations in the study area.

Acknowledgments. This study was carried out in the Health Physics and Radioactive Waste Management Unit (HPRWMU), Atomic Energy Research Establishment (AERE), Savar, Dhaka, within the framework of a research project. The authors wish to thank the Director of the INST, the Head of the HPRWMU, $A E R E$, and the management of the urea fertilizer factory, Narsingdi, for their kind support during this study.

\section{REFERENCES}

Abbady A.G.E., Uosif M.A.M., El-Taher A. (2005) Natural radioactivity and dose assessment for phosphate rocks from Wadi El-Mashash and El-Mahamid Mines, Egypt, J. Environ. Radioact. 84 (1), 65-78.

Ahmed N.K., El-Arabi A.G.M. (2005) Natural radioactivity in farm soil and phosphate fertilizer and its environmental implications in Qena governorate, upper Egypt, J. Environ. Radioact. 84, 51-64.

Alam M.N., Chowdhury M.I., Kamal M., Ghose S., Banu H., Chakraborty D. (1997) Radioactivity in Chemical Fertilizers Bangladesh Used in Bangladesh, Appl. Radiat. Isotopes 48 (8), 1165-1168.

Alam M.N., Chowdhury M.I., Kamal M., Ghose S., Islam M.N., Anwaruddin M. (1999) Radiological Assessment of Drinking Water of the Chittagong Region of Bangladesh, Radiat. Prot. Dosim. 82, 207-214. 
Alcaraz Pelegrina J.M., Martinez-Aguirre A. (2001) Natural radioactivity in ground waters around a fertilizer factory complex in south of Spain, Appl. Radiat. Isotopes 55, 419-423.

Al-Saleh F.S., Al-Berzan B. (2007) Measurements of natural radioactivity in some kinds of marble and granite used in Riyadh region, J. Nucl. Radiat. Phys. 2 (1), 25-36.

Bolivar J.P., Garcia-Tenorio R., Vaca F. (2000) Radioecological study of an estuarine system located in the south of Spain, Water Research 34 (11), 2941-2950.

Bolivar J.P., Garcia-Tenorio R., Mas J.L., Vaca F. (2002) Radioactive impact in sediments from an estuarine system affected by industrial wastes releases, Environment International 27, 639-645.

Brigden K., Stringer R., Santillo D. (2002) Heavy metal and radionuclide contamination of fertilizer products and phosphogypsum waste produced by the Lebanese chemical company, Lebanon, Greenpeace Research Laboratories, Technical Note 13.

Butchaiah G., Bonnet S., Menke C., Garivait S. (2009) Air pollutant emissions from rice straw open field burning in India, Thailand and the Philippines, Environmental Pollution 157, 1554-1558.

Cevik U., Damla N., Karahan G., Çelebi N., Kobya A. (2006) Natural radioactivity in tap waters of Eastern Black Sea region of Turkey, Radiat. Prot. Dosim. 118 (1), 88-92.

Chowdhury M.I., Alam M.N., Hazari S.K.S. (1999) Distribution of radionuclides in the river sediments and coastal soils of Chittagong, Bangladesh and evaluation of the radiation hazard, Appl. Radiat. Isotopes 51, 747-755.

Chowdhury M.I., Kamal M., Alam M.N., Yeasmin S., Mostafa M.N. (2006) Distribution of naturally occurring radionuclides in soils of the southern districts of Bangladesh, Radiat. Prot. Dosim. 118, $126-130$

Conceicao F.T., Bonotto D.M. (2006). Radionuclides, heavy metals and fluorine incidence at Tapira phosphate rocks, Brazil, and there by products, Environmental Pollution 139, 232-243.

El-Arabi A.M., Abbady A.G.E., Khalifa I.H. (2007) Radioactive and geochemistry characteristics of the Garnetiferous Granite of Um Sleimat area, Egypt, J. Earth Sciences 1 (1), 9-20.

El-Aydarous A. (2007) Gamma radioactivity levels and their corresponding external exposure of soil samples from Taif governorate, Saudi Arabia, Global J. Environmental Research 1 (2), 49-53.

El-Bahi S.M., El-Dine N.W., El-Shershaby A., Sroor A. (2004) Elemental analysis of Egyptian phosphate fertilizer components, Health Phys. 86 (3), 303-307.

Ghose S., Alam M.N., Islam M.N. (2000) Concentrations of ${ }^{222} \mathrm{Rn},{ }^{226} \mathrm{Ra}$ and ${ }^{228} \mathrm{Ra}$ in surface sea water of the Bay of Bengal, J. Environ. Radioact. 47, 291-300.

Huy N.Q., Luyen T.V. (2006) Study on external exposures doses from terrestrial radioactivity in Southern Vietnam, Radiat. Prot. Dosim. 118, 331-336.

Hopke P.K. (2009) Contemporary threats and air pollution, Atmos. Environ. 43, 87-93.

Khan K., Khan H.M., Tufail M., Khatibeh A.J.A.H., Ahmad N. (1998) Radiometric analysis of hazara phosphate rock and fertilizers in Pakistan, J. Environ. Radioact. 38 (1), 77-84.

Khalifa A.N. (2004) Natural Radioactivity of Ground and Drinking Water in Some Areas of Upper Egypt, Turkish J. Engineering and Environmental Science 28, 345-354.

Khater A.E.M., Higgy R.H., Pimpl M. (2001) Radiological impacts of natural radioactivity in AbuTartor phosphate deposits, Egypt, J. Environ. Radioact. 55, 255-267.

Labidi S., Dochraoui M., Mahjoubi H., Lemaitre N., Salah R.B., Mtimet S. (2002) Natural Radioactive Nuclides in Some Tunisian Thermo-Mineral Springs, J. Environ. Radioact. 62, 87-96.

Loganathan P., Tillman R.W., Parfitt R.L. (2007). Interactive effects of soil acidity and fluoride on soil solution aluminium chemistry and barley root growth, Environmental Pollution 145 (3), 778-786.

Mehra R., Singh S., Singh K., Sonkawade R. (2007) ${ }^{226} \mathrm{Ra},{ }^{232} \mathrm{Th}$ and ${ }^{40} \mathrm{~K}$ analysis in soil samples from some areas of Malwa region, Punjab, India using gamma ray spectrometry, Environ. Monit. Assess. 134, 333-342. 
Mireles F., Davila J.I., Quirino L.L., Lugo J.F., Pinedo J.L., Rios C. (2003) Natural soil gamma radioactivity levels and resultant population dose in the cities of Zacatecas and Guadalupe, Zacatecas, Mexico, Health Phys. 84, 368-372.

Mourad N.M., Sharshar T., Elnimr T., Mousa M.A. (2009) Radioactivity and fluoride contamination derived from a phosphate fertilizer plant in Egypt, Appl. Radiat. Isotopes 67, 1259-1268.

Nuclear Energy Agency Organization for Economic Cooperation and Development, NEA-OECD (1979) Exposure to Radiation from Natural Radioactivity in Building Materials, Report by the NEA Group of Experts, OECD, Paris.

Ogunleye P.O., Mayaki M.C., Amapu I.Y. (2002) Radioactivity and heavy metal composition of Nigerian phosphate rock: possible environmental implications, J. Environ. Radioact. 62, 39-48.

Olszewska-Wasiolek M. (1995) Estimates of the occupational radiological hazard in phosphate fertilizers industry in Poland, Radiat. Prot. Dosim. 58, 269-276.

Radenkovic M.B., Alshikh S.M., Andric V.B., Miljanic S.S. (2009) Radioactivity of sand from several renowned public beaches and assessment of the corresponding environmental risks, J. Serbian Chem. Soc. 74 (4), 461-470.

Righi S., Betti M., Bruzzi L., Mazzotti G. (2000) Monitoring of natural radioactivity in working places, Microchem. J. 67, 119-126.

Righi S., Lucialli P., Bruzzi L. (2005) Health and Environmental Impacts of a Fertilizer Plant-Part I: Assessment of Radioactive Pollution, J. Environ. Radioact. 82 (2), 167-182.

Salbu B., Skipperud L. (2009) Speciation of radionuclides in the environment, J. Environ. Radioact. 100, 281-282.

Sam A.K., Holm E. (1995) The natural radioactivity in phosphate deposits from Sudan, Sci. Total Environ. 162, 173-178.

Santos A.J.G., Mazzilli B.P., Fávaro D.I.T., Silva P.S.C. (2006) Partitioning of radionuclides and trace elements in phosphogypsum and its source materials based on sequential extraction methods, $J$. Environ. Radioact. 87 (1), 52-61.

Saueia C.H.R., Mazzilli B.P., Fávaro D.I.T. (2005) Natural radioactivity in phosphate rock, phosphogypsum and phosphate fertilizers in Brazil, J. Radioanal. Nucl. Chem. 264 (2), 445-448.

Saueia C.H.R., Mazzilli B.P. (2006) Distribution of natural radionuclides in the production and use of phosphate fertilizers in Brazil, J. Environ. Radioact. 89 (3), 229-239.

Somlai J., Horvath G., Kanyar B., Kovacs T., Bo-drogi E., Kavasi N. (2002) Concentration of Ra-226 in Hungarian Bottled Mineral Water, J. Environ. Radioact. 62, 235-240.

Tufail M., Iqbal M., Mirza S.M. (2000) Radiation doses due to natural radioactivity in Pakistan marble, Radioprotection 34, 355-359.

Uchida S., Tagami K., Hirai I. (2007) Soil-to-plant transfer factors of stable elements and naturally occurring radionuclides, J. Nucl. Sci. Technol. 44 (4), 628-640.

UNEP (United Nations Environmental Programme Industry and Environment) (1998) Mineral fertilizer production and the environment, the fertilizer industry's manufacturing processes and environmental issues. Technical Reports No. 26-Part 1.

UNSCEAR (1982) Ionizing radiation: sources and biological effects. United Nations, New York.

UNSCEAR (1988) Sources, effects and risks of ionizing radiation: 1988 report to the General Assembly, with annexes, New York.

UNSCEAR (1998) Sources and Effects of Ionizing Radiation, United Nations, New York.

UNSCEAR (2000) Effects and risks of ionizing radiations, New York.

Wang X., Sato T., Xing B., Tao S. (2005) Health risks of heavy metals to general public Tianjin, China via consumption of vegetables and fish, Sci. Total Environ. 350, 28-37. 